\title{
Writing change: \\ affirmative action as a tool for newspaper transformation at the Durban Post ${ }^{\mathrm{i}}$
}

Miriam Leshin

\begin{abstract}
This study explores the use of affirmative action as a tool for transformation in the mainstream English-language press in South Africa through a case study at The Durban Post. It seeks to understand the extent to which the newspaper has transformed its staff, coverage and readership in the eyes of its reporters and editors. Additionally, this paper investigates staff views on the implementation of affirmative action in their workspace and this policy's potential to impact on transformation. Observation, interviews and document analysis were used for data collection. This study finds that though The Durban Post's staff has transformed to some extent, the majority of staff members interviewed feel that the paper has yet to achieve significant transformation of coverage, readership and power structure, due to societal and internal systemic factors.

\section{Key words}

Affirmative action, coverage, staff, English-language press, newspaper transformation, readership.

\section{Introduction}

For centuries, English-language newspapers in South Africa were written by whites for whites. Thus, in the post-1994 age of transformation, these papers now attempt to diversify both their staff and their readership. While other sectors of South African society seek to transform their staff as well, newspapers face the additional challenge of transforming their product - in terms of coverage and readership - to reflect the diversity of the rainbow nation. In order to better understand the challenges that mainstream English-language newspapers face in achieving transformation of coverage and readership, this paper centers on the perceptions of staff members at The Durban Post through a case study approach.
\end{abstract}


The Durban Post's very recent diversification of its newsroom staff renders this study especially timely. This paper aims to understand staff perceptions of the extent to which this recent demographic transformation has actually translated into transformation in the more fundamental aspects of content and readership. A related but secondary concern is the extent to which reporters and editors believe that affirmative action as implemented at The Durban Post is an effective tool for transformation.

\section{Literature review}

The publication of the first local South African newspaper in 1800 marked the birth of a mainstream press largely produced for whites, by whites (Fourie, 2001:35). Although three other racially-based press groupings emerged over the subsequent two centuries - an ideology-driven Afrikaans press, a black press and alternative presses - the profit-driven, Eurocentric, mainstream, English-language press dominated; largely because of its entrenched professional and commercial presence (Berger,1999:19).

Apartheid only exacerbated the segregation of newspapers and the predominance of the white mainstream press, which provided limited coverage of the social and political struggles of this time (Fourie, 2001:52). Only when the mainstream press found a market in the increasing numbers of literate blacks in the 1960s and 1970s, did it seek to engage black readers through the introduction of regular township editions (Fourie, 2001:52). Although black journalists often reported for the township editions, these inserts were still under the control of the white editorial hierarchy and thus Eurocentric in perspective (Tomaselli and Louw, 1991:115). These journalists of color had to work in segregated newsrooms with separate staff bathrooms and canteens, and many formed unions in response to workplace discrimination (Raubenheimer, 1991:95).

Beginning in the 1930s and flourishing by the 1960s and 1970s, black journalists and their liberal allies founded alternative newspapers to report on the struggles against apartheid from black perspectives $^{\text {ii }}$. (Fourie, 2001:52-54). The end of apartheid in the early 1990s, however, eliminated the market for an alternative press to deliver exclusive news on the struggle (Fourie, 2001:55). Alternative media also faced financial difficulties, as much of their overseas funding was withdrawn with the termination of apartheid (Fourie, 2001:55). Additionally, mainstream papers began integrating their township editions into their regular papers - now attempting to cover South African society in its entirety - further diminishing the need for an alternative press. Ironically, the new South Africa, for which the alternative press had fought, did not have a place in it for the alternative press (Tomaselli \& Louw, 1991:225).

The end of apartheid in 1994 necessitated the emergence of a new South Africa, which has since sought to transform itself politically, socially and economically, in addition to attempting to forge a common national identity (Bertelsmann, 2008). In the new South Africa, private and public institutions seek to remake themselves according to the country's newly acquired democratic ideals: 'to change the ways things were done, and to introduce new and better, more democratic, more demographically equitable, more politically and gender sensitive ways of 
doing things' (Teer-Tomaselli \& Tomaselli, 200: 123). At its core, transformation in South Africa is a combination of "the development agenda" with "the pursuit of freedom and

democracy" (Manganyi, 2004:4). Moreover, due to its continuing presence in South African society, transformation has evolved into "a phenomenon of the socio-political landscape in its own right" (Manganyi, 2004:3).

The media in particular finds itself in a unique position within the politics of transformation. Media forms are simultaneously the "sites" of transformation - as they too seek to remake themselves in accordance with the new philosophy of inclusion - but they are also "instruments" of it: 'Media provide essential platforms for debate, information and education around issues shaping the kind of society we are, and the kind of society we wish to become... the media choose and frame the kinds of stories we read, see and hear' (Teer-Tomaselli \& Tomaselli, 2001:124). Additionally, the media's financial dependence on advertisements complicates its struggle to diversify its readership, as it must maintain its affluent white readership in order to continue to sell advertising space (Tomaselli, 2001:135).

In an effort to achieve transformation in all sectors of society, the newly elected African National Congress mandated workplace integration through law. The Employment Equity Act (1998) and the Promotion of Equality and Prevention of Unfair Discrimination Act (2000) collectively 'sought to achieve both demographic transformation and equal opportunity in employment by (a) eliminating unfair discrimination, (b) implementing affirmative action, and (c) policing these labour practices in newly established 'Equality Courts"' (Durrheim, 2007:117). The Employment Equity Act explains affirmative action as a way to redress the disadvantages in employment that designated groups ${ }^{\text {iii }}$ have experienced, by achieving equitable representation in all occupational categories and levels in the workforce (Alexander, 2007:94). While affirmative action seeks to bring more black people into the fold on the whole, the Broad-Based Black Economic Empowerment (BBBEE) bill of 2003 concentrates on black ownership and control specifically.

Both policies have impacted on the media industry in ownership and staffing respectively. Numerous formerly white-owned media conglomerates, such as Argus Holdings Ltd., sold parts of their company to black-owned firms in the late 1990s (Tomaselli, 2001:131). This is seen as blacks gaining allocative control, i.e. the authority to define overall goals and determine the distribution of the company's productive resources. Through affirmative action, blacks have gained operational control as well, which involves having daily authority over human and material resources, through new positions in editorial leadership: for example, nine major newspapers replaced white editors and/or deputy editors with black editors between 1994 and 2000 (Berger, 2001:166). Overall, more people of color than white people now work in the media industry, whereas whites predominated pre-1994 (Goga, 2001:214).

But despite this progress, racial discrepancies in salary and job categorisation still exist (according to a national UNESCO-sponsored research project launched in the late 1990s to examine the impacts of affirmative action in the South African media) (Goga, 2001:214). Top and senior management positions are still disproportionately occupied by whites, as are semi and 
unskilled labour positions by blacks. And when blacks and whites do the same jobs there is a discrepancy in their salaries, with the whites in every level but one earning more than blacks do on average (Goga, 2001:220).

The rapid transformation of the South African Broadcasting Company (SABC) is a telling example of the challenges of transformation. Although the formally pro-apartheid and white dominated company was essentially "turned on its head" within two years - in the appointment of Zwelakhe Sisulu as chief executive - the majority of its employees were still white in the late 1990s (Mthombothi, 1996). This presented many problems, such as changing the mindsets of current white employees who may have been unaccustomed to working with - or below - blacks, as well as recruiting and training qualified black journalists, many of whom were educated under apartheid (Mthombothi, 1996).

Academics disagree over the extent to which the South African media has transformed in actuality in the last decade. Guy Berger argues that the increasing numbers of black owners and editors point to important change as well as the potential for greater change (Berger, 2001:174). Berger's opponents, however, maintain that true transformation in the media can only be measured by the media's content and not simply the racial identities of a token few among its staff. The practitioners of this school of thought define transformation as being achieved when: '[the South African media] reflects, in its ownership, staffing, and product, the society within which it operates, not only in terms of race, but also socio-economic status, gender, religion, sexual orientation, region, language, etc' (Boloka \& Krabill, 2000:76). Similarly, South African journalist Rehana Rossouw reiterates this view: 'Transformation and diversity is not about numbers; it's about changing mindsets and structures of organizations. It is not about having the same number of women and black people in the newsroom as there is in society... [it's about] bringing their worldview and way of doing things into a newsroom' (Rossouw, 2005:225).

Ultimately, 'the extent, recommended directions, categories and standards of media transformation, and its range of possible manifestations, are not always agreed upon' (Tomaselli, 2004). Given this widespread disagreement among scholars and journalists alike - including those interviewed - it is beyond the scope of this paper to offer a precise definition of transformation. Moreover, since the intent of this paper is to illustrate staff members' perceptions of transformation, it is left to them to define transformation for themselves, as they see it and as they evaluate it.

\section{Background: The Durban Post ${ }^{\mathrm{iv}}$}

Founded in 1852, The Durban Post began as a white-oriented newspaper, owned by a family company. The paper had close colonial ties, as one of its first editors was the premier of the Natal British Colony. Financial difficulties in the 1980s forced the family to sell the paper to the European-owned Durban Newspapers ${ }^{\mathrm{v}}$ company, which then initiated cost-cutting and staff freezes in hopes of rescuing the newspaper (Wilks, 1977).

In the early 1990s, however, the paper was still doing badly financially. In addition to diversifying the paper's white male readership, the new editor at the time brought in a consultant, 
who suggested that The Durban Post and one of Durban Newspapers' other papers differentiate their markets - the former shifted to business, politics and an explicitly up-market readership, while the latter went for a popular, tabloid format. To further cement this break, The Durban

Post doubled its cover price - a move which arguably cost the paper some of its loyal readers, but did succeed in differentiating the formerly competing papers.

The Durban Post's economic struggles did not end in the 1990s, as the paper has been downsising since. The formerly 20 to 25 -reporter newsroom is now composed of about 14 reporters. Twenty years ago the newspaper typically had 20 to 30 news pages, whereas now it prints between five and six in each issue. This downsising - among other factors - has resulted in what many at The Durban Post refer to as the "juniorisation" of the newsroom. Over the last two decades, the paper's senior staff has been largely depleted: out of 14 reporters, only three are senior reporters, and junior reporters comprise the remainder.

The formerly hierarchical and experienced newsroom that senior reporters recalled has transformed, as it is now not uncommon for junior reporters - even interns - to write front-page stories. To assist these inexperienced reporters in meeting the paper's high expectations for them, the assistant editor recently implemented a mentoring programme, in which senior and junior reporters are matched by beat.

While the newsroom staff has diversified gradually over the last 10 years, the last few years have seen dramatic changes in staff demographics, as the majority of reporters are now black women, as opposed to the white men of the past. Readership has also transformed greatly, as the majority of Durban Post readers are Indian (38 percent) not white (36 percent), and African readers are close behind in proportion ( 23 percent). ${ }^{\text {vi }}$

According to its 2003 Business Plan presentation ${ }^{\text {vii }}$, The Durban Post's mission statement reads:

The Durban Post is an aspirational newspaper positioned to appeal to decision-makers and achievers. The title gives readers a head start through its authoritative, challenging reporting, commentary and interpretation - and through its bright, human and topical coverage.

In particular, the majority of The Durban Post's readers fall in Living Standard Measurements 8 -10. The Durban Post markets itself as nonracial and as appealing "to upmarket groups across all races" (2003 Business Plan).

Durban Newspapers most recently published a company-wide affirmative action policy in

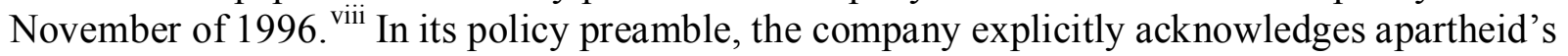
discrimination against the majority of South Africans - Africans, Coloureds and Indians - as well as its discrimination against its own staff. According to its policy, Durban Newspapers values affirmative action as a tool of holistic transformation: '[Transformation] should be extended to 
totally transform the company's culture to reflect and value the diversity of its people' (DN Affirmative Action Policy).

Durban Newspapers presents its affirmative action policy as a temporary and multi-faceted process. The company set targets in 1996 - to be met by the end of 1999 - that outline exact

racial percentages to be achieved in each level of the Paterson employment grades. Moreover, Durban Newspapers outlined new, broad-based hiring regulations to ensure the recruitment of blacks, and also allocated funds for training and development programmes that seek to educate and retain new black recruits. Additionally, the company created an Affirmative Action Monitoring Committee to implement and evaluate the policy. No update on this 1996 policy could be located.

\section{Methods}

This paper utilises a case study approach to provide in-depth description of one particular place The Durban Post - at one particular time (Stake, 1995:38). Qualitative case studies seek to provide "thick description," as well as an "understanding of human experience [as] a matter of chronologies more than of causes and effects" (Stake, 1995:39). Accordingly, this case study offers a window into staff members' personal and professional experiences with transformation and affirmative action, rather than seeking to definitively prove the exact causes and effects of these trends. Given the short time period allotted for research - just under two weeks - the case study approach served as the best possible method for an informed understanding of this complex topic. Major factors in selecting The Durban Post for this paper were its staff members' willingness to participate in this study, as well as its convenient geographic location. This newspaper's formal identity is concealed at the request of its editors.

All field research was gathered at The Durban Post, where I spent approximately 30 hours in the editorial newsroom over the course of two weeks, observing and interviewing staff. For the observation, I sat in the newsroom for several hours each day, taking note of both personal and professional interactions among reporters. The bulk of my research, however, came from 11 indepth, semi-structured, one-on-one interviews, which ranged from 15 minutes to an hour and a half, of a purposeful sample of maximum variation. I interviewed eight reporters, who ranged in age and race, and three people in management. ${ }^{\mathrm{ix}}$ The interviews with the latter allowed me a context in which to understand the on the ground perspectives I got from reporters.

Because of the major time constraints of this project and the hectic schedules under which most staff members operated, interviewees were chosen based on availability. Each day, the news editor of the paper pointed me to two reporters who would have time to be interviewed on that particular day. We also met separately to discuss the sample, in order to ensure that it was diverse in both experience and background. Since eight out of 14 reporters were interviewed, the sample is fairly representative. 
I also used document analysis of the following documents: Durban Newspapers' Affirmative Action Policy, The Durban Post's 2003 Business Plan presentation, and a poster on readership demographics.

My study is limited by several factors. Since my research occurred over two weeks, I witnessed a very small fraction of time in the professional lives of my participants. By coincidence, I happened to be at The Durban Post in the days leading up to and on following the national elections, which may have altered the newsroom atmosphere. Additionally, while my presence as

an outsider allowed me an unbiased, detached perspective, it also may have altered the newsroom atmosphere. My identity as a white American intrigued newsroom staff enough to grant me access and interviews; however, my race could clearly have inhibited my African or Indian interviewees from speaking freely on this emotionally-charged issue.

\section{Findings}

On the wall of The Durban Post's multi-racial newsroom - in which the majority of reporters are African females - sits a large picture from 1992 that reads “The Durban Post's 130 $0^{\text {th }}$ Birthday" and depicts an almost entirely white and male staff standing in the very same newsroom, smiling up at the camera.

Yet while the paper's staff racial profile has changed dramatically, the extent to which this change has led to similar transformation of the newspaper's coverage and readership is contested among staff members. To fully understand their views, this paper first describes the working environment in which they find themselves and their personal opinions on the concept of affirmative action. The study then explores staff members' conflicting perceptions of affirmative action and transformation - in terms of changes in content, readership and power structure - at their newspaper.

\section{Working environment}

Almost every reporter or editor with whom I spoke commented on the friendly and open atmosphere of their newsroom. People spoke of the newsroom as a safe space in which they could freely express their views. In addition to the annual work Christmas party, staff also get together for team-building activities, such as volunteer visits to The Durban Post Children's Home, which the paper sponsors. In terms of after-work social life, there was more of a generational than racial divide, as younger reporters spoke of braai-ing together, while older reporters were aware of, but uninterested in, these activities, as they were busy with families.

Views on the quality of work in the newsroom also differed by age. Most participants expressed pride in their newspaper and appreciation for the strong work ethic in the newsroom; some senior participants, however, found their working environment neither challenging nor stimulating. This was said to result from the experience gap between the few top senior reporters and the majority junior reporters, some of whom are just out of university. But despite this gap, the two groups seemed to have a mutual respect for each other: junior reporters expressed appreciation 
for the guidance they received from their older colleagues and senior reporters felt their younger counterparts rose to the paper's high expectations for them.

But despite the open and honest workspace I observed and heard about, complications still arose. Some reporters felt that certain individuals in the newsroom needed to change their perceptions of those of the other races: in particular that white staff needed to change how they thought about black colleagues and township news. Others noted that beats are often assigned by race, both intentionally because of language barriers and unintentionally because of habit or assumption. For example, for election coverage, certain reporters were dispatched to polling places where other members of their race would be the predominant voters. Interestingly, some reporters saw

this racially-based assignment allocation system as advantageous to the paper, as it allowed The Durban Post to get the best possible person - someone who knew the cultural norms and background - to cover an event. Others, however, felt this system locked them in to certain beats they did not necessarily want to cover, and even occasionally led to their being made fun of for their assigned beat. Some noted the presence of racial jokes around the workplace, though they insisted they felt comfortable in spite of them.

\section{Affirmative action as a concept}

Every single reporter or editor interviewed expressed support for affirmative action, using phrases like "even playing field" and "address imbalances." The impact of affirmative action in this country, however, was contested. A few participants alleged that affirmative action had actually impoverished the country in a way, as it prompted a "brain drain", in which many educated whites emigrated because they felt the policy limited their opportunities. Others complained that the policy catered to the black elite and didn't actually produce broad-based progress. Participants of all races pointed to the misuse and abuse of affirmative action, especially in the government sector, where unqualified black people have sometimes been appointed to positions solely on the basis of skin color. On a similar note, many felt that the policy overlooked the importance of training for affirmative action hires. One participant put it bluntly, '[Companies just say] "shit", we need a black guy!' (Interview 2).

Some in the newsroom felt that affirmative action should only be temporary and wished there was an alternative; however, others felt the policy did not go far enough in redressing the still recent past.

\section{Affirmative action as implemented at The Durban Post}

Reporters and editors alike were confused about the company's affirmative action policy. One reporter even denied that any staff member had been recruited through affirmative action. The editors, however, explained that the paper had not met all of its targets, but that that was acceptable, because the targets were for the company on the whole to meet. Although one editor noted that several years ago the company explicitly told the newspaper to stop hiring white people temporarily, this is no longer the case. Instead, if two candidates earn equal scores on their interviewer's rubric - of which the minimum for hire is 80 percent - -the paper is required to hire a woman over a man or a black person over a white person according to the following 
ranking: African, Coloured, Indian, White (Interview 3). This strategy is to be used until targets are met.

An interesting caveat is that this endpoint at which targets are met means different things to different people. While some insisted that the newsroom should reflect the population on the whole demographically, others felt that staff racial composition should instead mirror that of the paper's market. The former would imply that the newsroom should be majority African as is the country, while the latter means that the staff would be majority Indian and white just like its readership. One person suggested that the newsroom's racial composition should be proportionate to the racial composition of skilled and educated people in this country.

While people's understanding of the paper's affirmative action policy varied to a surprising extent, views on the policy's implementation directly contradicted each other. In particular, many people thought that young inexperienced recruits were capable of rising to editors' expectations, while others felt that more training was absolutely necessary to bridge the skills gap.

Towards the former argument, several people felt that though young reporters were not at the height of their careers, they were competent and well-qualified with tertiary degrees. One senior reporter pointed out that African reporters sometimes have an interesting advantage over white reporters: having grown up in the black community, and then transitioned to working in a mostly white industry, they have knowledge of both communities, as well as the unique ability to move between the two - both of which widen the scope of events they are qualified to cover. This reporter cited whites' unfamiliarity with African languages and cultural norms as a huge limitation for white journalists attempting to work in Zulu-majority KwaZulu-Natal.

Many emphasised that more training and development programmes were needed for inexperienced journalists of all races. Some suggested expanding the paper's current mentoring program- which only applies to the few beats that currently have senior reporters - and providing in-house training courses on various subjects such as news-writing skills. Moreover, editors explained that because English is the second language for many of its new reporters, this necessitates more thorough editing of stories on the part of the editors. Many people expressed deep disappointment that The Durban Post does not do enough for its young reporters and expects too much from them: one editor lamented, "We're very unfair on our young guys" (Interview 2).

\section{Transformation at The Durban Post}

The extent to which transformation has actually occurred at The Durban Post depends very much on with whom you speak. Some in the newsroom felt that the newspaper had completely transformed since 1994, bringing in both black and female voices. Others, however, felt that the newspaper hadn't changed at all because whites still effectively owned and controlled media companies, though blacks did own shares in several. The majority of people struck a balance between these two views, admitting that there had been significant change - especially in the last 
decade - but there was still a long way to go towards achieving true transformation. Despite the paper's best efforts towards this end, the majority of the newsroom felt that the newspaper was still white-dominated in its content, its readership, and its power structure. In almost every interview the question became about who should drive newspaper transformation, staff or readers?

\section{Changes in content}

Views on the extent to which The Durban Post has become less Eurocentric in content vary somewhat by race. The majority of African staff members felt that the newspaper had not done nearly enough to transform its content, while many Indians and whites lauded the newspaper for

its efforts towards diversification of coverage. Some in the latter group, however, were aware of the former complaint, but felt that such disconnect in opinion made for healthy debate.

Most people, however, noted that the newspaper had made substantial progress in broadening its coverage. The sub-editors and those in charge of making final copy decisions try to make sure there are black as well as white faces in the newspaper. Many noted that political coverage was a particularly strong point for the newspaper, because its Zulu-speaking reporters were able to speak to politicians and local leaders in their own language. This also allows the paper to cover rural politics, as constituents in Zululand often don't speak English. In general, the newspaper's coverage has broadened in this way, integrating African-based stories in to the fold. Many noted that the paper's diverse staff brings in diverse ideas for articles to meetings, thus allowing the paper to cover issues across all South African communities.

According to some, the paper seeks to utilise this expanded coverage of black communities to dispel negative stereotypes. One reporter explained that the paper no longer included race in stories - especially crime-related ones - to avoid perpetuating stereotypes. Similarly, at morning meetings, reporters will occasionally brainstorm positive stories about black people.

Despite the above progress, however, towards more inclusive coverage, many staff members felt that the paper's efforts continually fell short. As mentioned earlier, one repercussion of widening coverage has been the establishment of a race-based assignment allocation system, that on one hand gives the newspaper "a more widened area to work form" (Interview 5), but on the other hand is seen by many African reporters as locking them into certain beats. One African reporter felt that the system restricted her coverage to such an extent that it detracted from her passion for journalism. She noted that though language is sometimes a legitimate barrier in assigning reporters to stories, the paper should send reporters out based on their ability not on their race.

Complaints about the paper's white-oriented coverage varied. Some argued that there was not enough coverage of black people in general, especially the black poor. Conversely, others felt that the paper did not cover the black middle class enough, and that whenever blacks were covered they were portrayed as poor and helpless. 
In addition to criticism of the paper's story and angle choices, many people expressed concern over the prominence and length given to certain stories over others. The most common perception here was that white stories were often longer and featured towards the front of the paper more than were black stories. Many emphasised that the way crimes were reported was particularly problematic. When a white businessman was killed this would make the front-page, but when a black businessman was killed this would receive little if any coverage. When a white girl was raped in a suburb this would be the paper's lead page-one story, but when three black girls were raped in Umlazi this would be buried within the newspaper's pages. Suburban news in places like Umhlunga were seen as given more prominence than township news from Cato Manor or Kwa Mashu, which was often relegated into short news briefs. One staff member said that gross discrepancies like this kept him up at night.

While almost everyone was aware of this issue, justifications for it differed greatly. Some insisted that the paper was simply catering to its white and Indian, middle and upper class readership, though they acknowledged that black reporters may see this as biased coverage. Others, however, felt that the readership justification just re-positioned the issue as one of class instead of one of race. These staff members pointed out that the emphasis of white over black news has the potential to alienate the paper's recent and small black middle class readership. Although these upper-income black readers may now live in suburbs, many still visit friends and family in townships and are invested in events that happen in the black community, according to one staff member. Thus, this staff member said, the paper should cover all human issues especially crime - in the same way, catering to a human audience, not one dominated by one race or another. One reporter echoed these sentiments, explaining that it's a contradiction of journalistic ethics to tailor news coverage to those who the paper perceives as its readers.

While many acknowledged this ongoing debate among staff members, people interpreted it differently. White and Indian staff tended to see these differences in opinion as fodder for a healthy debate. African staff, however, tended to see the paper's lack of change as troubling, and for some, troubling enough to make them quit journalism. One white reporter felt that black journalists may have a better idea of to what extent the paper's content had actually transformed.

These conflicting perceptions illustrate several complications that newspapers seeking to transform their coverage inevitably face. Many people noted that the newspaper's white-oriented history greatly restricts it from moving forward, as it is difficult to get long-time staff members and readers to see the paper differently, despite the paper's best efforts to change. The legacy of apartheid means that people - including editors and reporters - still largely live in separate worlds, which can cause staff members to occasionally step on each other's toes in the newsroom, according to one reporter.

Similarly, the paper's financial need to maintain wealthy white readers impedes its ability to transform. While many reporters argued that the paper's staff should drive transformation by selecting stories it finds newsworthy, the editor felt that the paper should cater to readers' interests. The editor felt that transformation was a delicate process that had to evolve naturally, as the paper needed to ensure that it maintained its old readership for financial reasons. 
Moreover, he warned of an instance at another English-language newspaper in which speedy transformation backfired. The paper's black editor wrote an editorial expressing his disgust at listening to the English and Afrikaans portions of the South African National Anthem at a rugby game. The editorial frustrated the newspaper's white readers, many of whom wrote letters to the editor in which they criticised him for not reconciling the past. The paper lost a significant portion of its white readership and faced financial troubles because of it. Accordingly, the editor of The Durban Post felt that transformation could not be 'shoved down people's throats' (Interview 3).

\section{Changes in readership}

The Durban Post thus walks a tight rope in trying to bring in new black readers while not alienating its historically white and somewhat conservative readership. One white senior reporter noted that working during apartheid was easier at times because she was catering to a single demographic market, which she knew how to cover. The extent to which the paper's readership has changed - or rather, changed enough - since 1994 is contested among staff. While some pointed to the inclusion of the new black middle-class into the paper's readership as a significant achievement, others felt that this was not enough in the way of readership transformation.

Those who lauded the paper's new black affluent readers felt that the paper's business insert brought in more black readers as, according to some, business is now dominated by black people. Some felt that the increased presence of black bylines in the newspaper was incentive for black people to pick up the newspaper and read. Others, however, argued that the paper's readers were still majority white (or Indian) and conservative, and drove transformation to an upsetting extent.

The fact that people working at the same newspaper have entirely different perceptions of changes in readership stems from people's differing perceptions of the paper's intended readership. Some felt that the paper was published strictly for its intended upmarket readership, and therefore had achieved appropriate transformation, as the racial composition of its readership now mirrors that of the middle and upper income groups that it is aiming to serve. Others, however, argued that The Durban Post should be aimed at all South Africans, regardless of race, class, or what market its advertisers wanted to see.

Several complications make the diversification of the paper's readership difficult. Across race, readership has been declining for decades (Interview 3). The combination of high unemployment rates and the current economic recession limit the number of South Africans who are in a financial position to actually purchase the newspaper. The internet also offers free and sometimes reputable coverage that similarly reduces newspaper sales. Additionally, one editor noted that the country's widespread literacy problem and related lack of a culture of reading was partially responsible for the paper's declining readership, and would make finding new generations of readers increasingly difficult. The paper also straddles two markets already, as it aims for the upmarket business community with its business insert, but also includes general coverage to try to maintain a broader audience as well. 
Thus, both industry-specific and societal factors complicate the transformation of The Durban Post's readership. Many reporters and editors were deeply frustrated by their paper's inability to change its readership, just as they were similarly frustrated by the related issue of changing coverage. They felt that their newspaper pandered to white and Indian interests for the sake of financial survival, and thus ignored its journalistic obligation to serve all South Africans. One reporter felt that the root of this problem was societal division, seen in the two economies and two states that comprise South Africa - one rich and white, the other poor and black - and inhibit the newly democratic country from developing a sense of national unity. He questioned, 'What does it mean to be South African?' and wondered to what extent it was even possible to produce one newspaper for such a diverse and divided country (Interview 11).

\section{Changes in power structure}

Like content and readership, the extent to which The Durban Post's power structure has changed and is capable of being changed depends immensely on who you speak to in the newsroom. While everyone admitted that the paper had come a long way in diversifying its staff, the majority felt that this was not enough change. Moreover, many felt as though the possibility for change in power structure - which has the potential to affect changes in content and readership was limited.

The few staff members who felt that The Durban Post's power structure had truly transformed particularly since 2000 - referenced the paper's majority African reporters, African news editor and female Indian assistant editor as evidence. The majority of people, however, felt that these were only token advancements for black people, as most of this new diversity is confined to reporter positions and not those in upper-level management. One reporter noted that a lecturer had termed this trend "the cappuccino effect," in which black people are recruited through affirmative action to work lower-level jobs (i.e. the espresso at the bottom) while white people still remain in powerful positions (i.e. the foam at the top); (Interview 8).

One staff member was particularly incensed with Durban Newspapers' use of this tactic, calling the company the "worst culprit" (Interview 1). He explained that out of the company's four English-language titles, only one has a black editor-in-chief, and white males still hold almost every top management position. He noted that this lack of progress sends a message to both readers and staff that the newspaper is not interested in full transformation. Several others wondered why the paper still had a white male editor.

This frustration with the power structure's inability to change was directed at staff, readers and ingrained systemic and societal obstacles. Some felt that the paper would never hire a black editor for fear of losing some (white) readers who read the paper because of its long-standing (white) editor. Others felt that a portion of The Durban Post staff would not be ready for a black editor, explaining that black editors had left majority white publications in the past because they felt unsupported by their subordinates.

Many noted, however, that the above problems often never had the chance to arise, because black journalists often felt unwelcome at historically white newspapers long before it became 
time for them to be considered for editor. As noted earlier, affirmative action opened many opportunities for blacks, especially in the government sector, and, accordingly, young black journalists often leave the field for more lucrative jobs in government. Some staff members noted, however, that black colleagues had left in the past because they saw no future for themselves at The Durban Post. Because they saw that the paper's management was still whitecontrolled, its content still white-orientedand its readership still white-dominated, they either no longer desired to move up further or thought it would be impossible. One staff member felt that young black reporters were often neglected and unsupported: 'They do not take care of their bright minds' (Interview 1). He felt that if management identified talented young black reporters early on and impressed upon them that they could eventually move up, many might turn down more lucrative government jobs to pursue careers in journalism.

But even if The Durban Post was careful to nurture its young black talent, this staff member noted that these reporters would still face challenges that could push them to leave their whiteoriented working environment. He noted that he often feels he has to defend stories about black people to others in the newsroom, even if he doesn't agree with them. Then there is the constant frustration that comes from pushing for more inclusive coverage but then being told that it's not in the paper's market. Lastly, he also noted that friends and family criticise him for being a pawn in the white establishment.

The combination of these systemic and societal factors makes transforming The Durban Post's power structure a daunting task. Many reporters, however, insisted that change at the top was necessary for any organic transformation. One young reporter felt that if more black people were in management positions, the newspaper could begin to reflect this diversity in its content.

Some, however, found the potential for the paper's power structure - and therefore overall orientation - to change extremely limited. One reporter noted that the media in South Africa is still divided, as white-owned media companies - in which black businessmen may have a share but do not necessarily have ultimate decision-making power - can project their biases on their newspapers. He cited many English-language newspapers' political slants towards the Democratic Alliance, explaining that this was not healthy for the country's new democracy. And even if blacks were brought into higher editorial positions, he said, they would just be powerless stooges for the white owners with the money above them (Interview 11).

\section{Conclusion}

This study finds that The Durban Post has been relatively slow to transform its content, readership and power structure, in the view of the majority in its newsroom. While staff members fully support the newspaper's use of affirmative action, many feel that it is not accompanied with the proper training needed to make its implementation as effective as possible. Additionally, the presence of directly contradicting perceptions on these issues within the newsroom proves to be a main obstacle in making change.

Like many English-language newspapers now seeking to be more inclusive, The Durban Post finds itself at an interesting cross-roads at this point in time. On one hand, it has made significant 
progress in transforming its staff, as its reporters are now majority African and majority female. Yet, on the other hand, its readers are still majority white and Indian. This situation has resulted in frustration among the paper's majority African staff members who often feel as though they are still working for a white-oriented institution. White staff members are aware of these concerns, but to a lesser extent, as they don't have the same daily reminders - such as race-based assignment allocation and backlash from their home communities - as their black counterparts. Many staff members say that ultimately, despite editors' accessibility and a culture of openness in the newsroom, it is these differing perceptions of progress, as well as financial restrictions and divisions within society, that limit the paper's possibilities for transformation.

\section{About the author}

Miriam Leshin is a senior at Wesleyan University in the United States, from which she will graduate in 2010 with a B.A. in African American Studies. In the spring of 2009, Leshin studied in Durban, South Africa with the School for International Training on its Reconciliation and Development programme. This article is a condensed version of Leshin's Independent Study Project, for which she was under the advisement of David Nothling of the University of KwaZulu-Natal.

\section{Contact Information}

mleshin@wesleyan.edu.

Miriam Leshin

207 Woodcliff Road

Newton, MA, USA 02461

\section{References}

Durban Newspapers: affirmative action policy. Nov., 1996. Provided by Human Resources.

The Durban Post Business Plan Presentation. 2003. Provided by The Durban Post editor.

The Durban Post Demographic Profile - total readership. 2008. Poster in conference room.

The following interviews were conducted at The Durban Post:

1. Personal interview: April 15, 2009.

2. Personal interview: April 15, 2009.

3. Personal interview. April 16, 2009.

4. Personal interview: April 16, 2009.

5. Personal interview: April 20, 2009. 
6. Personal interview April 20, 2009.

7. Personal interview: $\quad$ April 21, 2009.

8. Personal interview: $\quad$ April 21, 2009.

9. Personal interview. April 22, 2009.

10. Personal interview: April 22, 2009.

11. Personal interview. April 28, 2009.

\section{Literary sources}

Alexander, N. Affirmative action and the perpetuation of racial identities in postapartheid South Africa..In: Transformation: critical perspectives on Southern Africa. (63):

(2007). Durban: University of KwaZulu-Natal:

Berger, G. 2001. De-racialization, democracy and development: transformation of the South African Media, 1994-2000. In: Tomaselli, K \& Dunn, H. (eds.).Media, democracy and renewal in Southern Africa. Durban: Critical Arts Projects.

Berger, G.1999. Towards an analysis of the South African media and transformation, 1994-99. In: Transformation: critical perspectives on Southern Africa. 38: Durban: University of KwaZulu-Natal.

Bertelsmann, S. 2008. Shaping change - strategies of development and transformation: South Africa country report. http://www.bertelsmann-transformation-index.de/60.0.html?L=1

Boloka, G.,M. \& Krabill, R. 2000. Calling the glass half full: a response to Berger's Towards an analysis of the South African media and transformation, 1994-1999 In: Transformation: critical perspectives on Southern Africa.(43). Durban: University of KwaZulu-Natal.

Duncan, J. 2001. Talk left, act right: what constitutes transformation in Southern African media? In Tomaselli,K. \& Dunn,H. (eds.). Media, democracy and renewal in Southern Africa Durban: Critical Arts Projects.

Durrheim, K. 2007. The colour of success: a qualitative study of affirmative action attitudes of black academics in South Africa. In: Transformation: critical perspectives on Southern Africa. (64). Durban: University of KwaZulu-Natal..

Fourie, P. J. Ed: 2001. Media studies: institutions, theories and issues. (1). Lansdowne: Juta. Education:. 
Gade, P. J. 2004. Newspapers and organizational development: management and journalist perceptions of newsroom cultural change. Association for Education in Journalism and Mass Communication.

Glesne, Corinne.006. Becoming qualitative researchers: an introduction. Pearson Education Inc.

Goga, F. 2001. Issues of race and gender in The Durban Post-apartheid South African Media organizations, 1994-2000. In Tomaselli. K. \& Dunn, H. (eds.). Media, democracy and renewal in Southern Africa. Durban: Critical Arts Projects.

Hadland, A.,Louw, E.,Sesanti, S. \& Wasserman, H. Introduction. Power, politics, and identity in South African media. HSRC Press. [online].

Lehrman, S. 2006. Unconscious stereotypes slow newsroom diversity. Quill.

Louw, P. E.. \& Tomaselli, K. 1991. Impact of the 1990 reforms on the "Alternative Media". In Lous, P. E. \& Tomaselli, K.(eds.). The alternative press in South Africa. Pietermaritzburg:.Natal Witness Printing and Publishing Company (Pty) Ltd.

Manganyi, N. Chabani. 2004. On becoming a democracy: transition and transformation in South African society. Pretoria: Unisa Press.

Mthombothi, B.1996. South African broadcasting: desegregation at the top. Nieman Reports. 50.:(1): 60. Academic OneFile. Web:

http://find.galegroup.com/gtx/start.do?prodId=AONE\&userGroupName=31841.

Ntshakala, S. \& Emdon, C. The New African: hopes, struggles and problems. In Lous, E. P. \& Tomaselli, K. (eds.). 1991. The Alternative Press in South Africa. Pietermaritzburg: Natal Witness Printing and Publishing Company (Pty) Ltd.

Pratte, A. 2001. But there are miles to go: racial diversity and the American society of newspaper editors, 1922-2000. The Journal of Negro History. 86 (2):160-179).

Raubenheimer, L. 1991. From newsroom to the community: struggle in black journalism. In Lous, E. P and Keyan Tomaselli, K. (eds). The Alternative Press in South Africa. Pietermaritzburg: Natal Witness Printing and Publishing Company (Pty) Ltd.

Rossouw, R. 2005. The media and transformation in changing the_Fourth Estate: 
essays on South African Journalism. Hodlan, A. (ed.). Cape Town: HSRC Press.

Shalit, R.1995. Race in the newsroom. The New Republic (1995-10-02).

Stake, R. E. 1995. The nature of qualitative research. The art of case study research. New York :Sage Publications, Inc.

Teer-Tomaselli, R. \& Tomaselli, K. 2001. Transformation, Nation-building, and the South African media, 1993-1999. In Keyan Tomaselli, K. \& Dunn, H. (eds.). Media, democracy and renewal in Southern Africa. Durban: Critical Arts Projects.

Tomaselli, K. G. 2004. Transformation of the South African media. Critical Arts 18 (1) (2004): 1+. Academic OneFile. Web:

http://find.galegroup.com/gtx/start.do?prodId=AONE\&userGroupName=31841

Turok, B. 2008. Black Economic Empowerment (BEE)._From The Freedom Charter to Polokwane: The evolution of ANC economic policy. Cape Town: New Agenda South African Journal.

Wilks, T. 1977. For the love of Natal: the life and times of The Natal Post, 1852-1977. Pinetown, South Africa: Robinson \& Company.

\section{Appendix A: Interview schedules}

\section{Senior Management}

1.Professional background: What is your current position at The Durban Post? Describe your daily routine/responsibilities.How did you first get into journalism? Did you attend journalism school? What other newspapers have you worked at before here? How did you end up at The Durban Post? What other positions have you held at The Durban Post before this one? How/when did you move up?

2.Journalism: Why did you become a journalist? What do you see as the role of journalists in society? In South Africa?

3.Life at The Durban Post: How would you characterise the working environment here? What is the social life here? Do you go to your colleagues' houses? Call them on the phone? Are people friends?

4.The Durban Post background: Describe the history of The Durban Post (from its founding to now). How have the following evolved: 

a.) readership/circulation
b.) content, scope of coverage
c.) newsroom culture (editorial hierarchy, social life, recruitment methods, investigative tradition, stereotype of drinking "wild" boys)
d.) demographics of staff

\section{Affirmative Action:}

a.) Fact: What is The Durban Post's AA policy? How is it implemented?

b.) Opinion: How do you feel about AA in general? What about at The Durban Post? What is its goal? Is it achieved? Why do you think it exists here?

6. Impact: How, if at all, has AA impacted on content? How, if at all, has it impacted on social life here? (How does having a multi-racial newsroom impact on coverage and/or the newsroom environment?)

7. Transformation: In what ways has the SA press (and The Durban Post in particular) changed since 1994? In what ways does it still need to change? Ideas for how to do that? How has AA contributed, if at all, to the overall transformation of The Durban Post?

\section{Reporters}

1. Professional background: What is your current position at The Durban Post? Describe your daily routine/responsibilities. How did you first get into journalism? Did you attend journalism

school? What other newspapers have you worked at before here? How did you end up at The Durban Post? What other positions have you held at The Durban Post before this one? How/when did you move up?

2. Journalism: Why did you become a journalist? What do you see as the role of journalists in society? In South Africa?

3. Life at The Durban Post: How would you characterise the working environment here? What is the social life here? Do you go to your colleagues' houses? Call them on the phone? Are people friends?

4. Durban Post background: How have the following changed over your time here? ${ }^{\mathrm{x}}$

a.) readership/circulation

b.) content, scope of coverage 
c.) newsroom culture (editorial hierarchy, social life, recruitment methods, investigative tradition, stereotype of drinking "wild" boys)

d.) demographics of staff

5. Affirmative Action: How do you feel about AA in general? What about at The Durban Post? What is your understanding of AA at The Durban Post? What is its goal? Is it achieved? Why do you think it exists here?

6. How, if at all, has it impacted on content? How, if at all, has it impacted on social life here? (How does having a multi-racial newsroom impacton coverage and/or on the newsroom environment?)

7. Since 1994, mostly white English-language newspapers have tried to transform themselves in terms of both staff and product to serve the new South Africa. How has this worked at The Durban Post? In what ways have you seen it transform in your time here? In what ways would you still like to see it transform? How has AA contributed, if at all, to the overall transformation of The Durban Post?

8. Is there anything else at all around the themes of AA and transformation that you think about? If there was one thing you could change about the way things work at The Durban Post, what would it be? 
Appendix B: readership demographics (2008) ${ }^{\mathrm{xi}}$

Total readership: 190,000

Race:

White - 36\%

African - 23\%

Indian - 38\%

Coloured - 3\%

Gender:

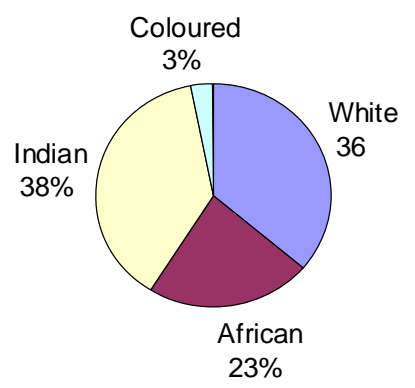

Male - 52\%

Female - 48\%

Living Standard Measurement (LSM):

$$
\begin{gathered}
10-28 \% \\
9-26 \% \\
8-18 \% \\
7-15 \% \\
6-9 \% \\
4 / 5-4 \%
\end{gathered}
$$

\section{Occupations:}

Full-time - 58\%

Part-time $-6 \%$

Students - 6\%

Retired - 13\%

Housewife - 12\%

Unemployed - 6\%

\section{Education:}

Below matric - 24\%

Matric - 51\%

Above matric - 26\% 


\footnotetext{
i "The Durban Post" is a pseudonym intended to protect the actual newspaper at which this project was researched.

${ }^{i i}$ While there were also white, right-wing alternative newspapers, this paper will only look at black, liberal alternative newspapers.

iii The Act defines "designated groups" as black people ("a generic term which means Africans, Coloureds, and Indians"), women, and people with disabilities. Accordingly, I will use "black people" to refer to Africans, Coloureds, and Indians throughout this paper.

${ }^{\text {iv }}$ I gathered the first section of my background information from a book on the newspaper's history, as well as an interview with the editor. The second section is a compilation of recent developments as told to me by senior reporters, the assistant editor, and the news editor.

v "Durban Newspapers" is a pseudonym intended to protect the actual company involved.

${ }^{v i}$ Statistics drawn from "The Durban Post Demographic Profile - Total Readership" poster in The Durban Post conference room. 2008. See Appendix B for full presentation of statistics.

vii “"2003 The Durban Post Business Plan Presentation." Provided by editor.

viii Durban Newspaper's affirmative action policy was provided by the company's Human Resources department in its Durban office.

${ }^{\text {ix }}$ See Appendix A for interview schedules.

${ }^{\mathrm{x}}$ I asked this question only to the three senior reporters interviewed who had been at the paper for several decades.

${ }^{x i}$ Statistics drawn from "The Durban Post demographic profile - total readership." 2008.
} 